\title{
The Magic Flute I and II as Holistic Healing Approach in Honor of Asclepios, Copernicus \& Co.
}

\author{
Konrad Frischeisen* \\ New Frontiers in Science Bildungsgesellschaft mbH, Munich, Germany
}

*Corresponding author: Konrad Frischeisen, New Frontiers in Science Bildungsgesellschaft mbH, Munich, New Frontiers in Science, Bildungsgesellschaft $\mathrm{mbH}$ (als gemeinnützig anerkannt), Ungererstr. 76, Germany.
Received Date: February 05, 2019

Published Date: February 26, 2019

\section{Clinical Image}

An abbreviated sustaining adaption of the Magic Flute continued and decoded according to split brain research of Sperry - applied and presented by Boys (B) and Girls (G) and a Speaker (S)

S: Sustaining Life, how human health depends on biodiversity', edited by Eric Chivian and Aaron Bernstein, was presented in IMPRS Interdisciplinary Symposium 2010 "New Frontiers in Science" by Prof. Bernstein, Medical School, Havard Univer-sity, see the painting of Katharina as result of well cooperating hemispheres of young human brains, participating in the crea-tion of a sustaining Magic Flute, inspired by Mozart, Asclepios and Haydn's Oratorium 'The Creation', based on the G enesis.

Tamino (T): 'Help me, otherwise I am lost...'Nr. 1, Introduction

G: He looses consciousness, as a serpent approaches. He seems to be strange here in Egypt. I take a wand in honor of Asclepios, who. was venerated in the antiquity in the theatre of Epidauros. The serpent is winding itself around it. I carry it to the priests of Asclepios.

Papageno: I am the birdcatcher, oh yes, always happy, hopsasa!', Nr. 2, Aria

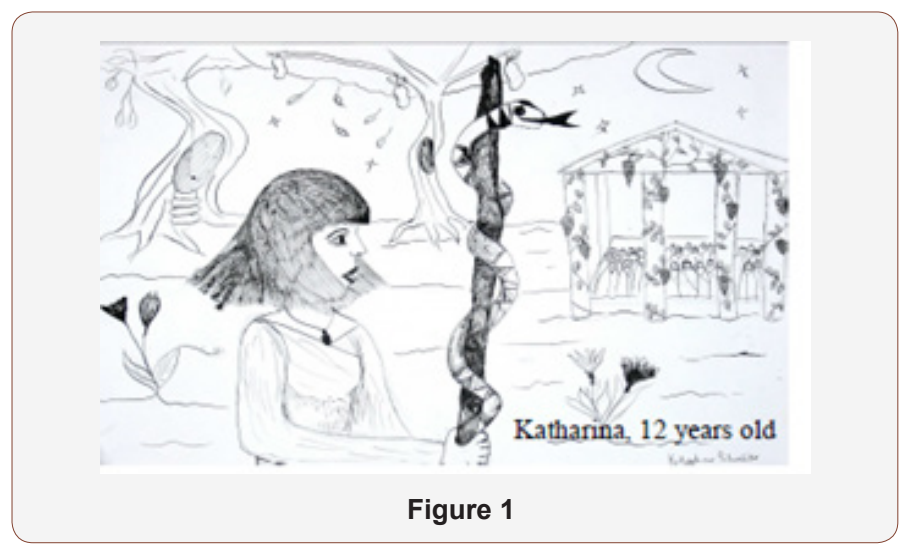

Tamino: awakened: 'Hey there' 'Tell me, who you are, my cheerful friend..."(Figure 1)

S: Tamino presents himself as prince, Papageno as human. Pretending to have overwhelmed the serpent, his mouth is padlocked. Tamino receives the Magic Flute and a picture of Pamina, Papageno (receives) magic bells, when his mouth is unlocked through grace of the Queen.

T: 'This picture is so enchantingly beautiful like no eye has never seen! I feel this picture is divine, my heart so deeply touched as it has ever been. I cannot name it, what could it be? It seems like fire burning in me. Shall this be love? Yes, love alone. If only I could find her!...' Nr. 3, Aria,

Queen (of The Night): '0 tremble not, my dear son- you will go to save her life, rescue her by your endeavour-, when I see you victorious, she will be yours forever...'Nr. 4, Aria Girls: Papageno finds Pamina, gains her confidence with her picture and admits tobe still without woman.

Pamina: 'Men, who feel love, will find a good heart.', Nr. 7, Duett Papageno: And to transform their longing into beauty is ladies ( $p$ ) art and duty. (...) Both. Man and wife, wife and man are reaching to the Deity.'

S: Pamina answers to the anxiously asking Papageno, what they should say to the arriving Sarastro: 'The truth...' All:' Could all liars get locks before their mouths, instead of denunciation and hatred, love and brotherhood would yield a better generaion...'

S: Following Schiller, poet and medical doctor, brotherhood can heal us. Supported by graceful girls, the boys present a sustaining future, teaching Tamino to be steadfast, patient and silent. The Queen of the Night is furious, considering the dominating ruler Sarastro as evil as he had robbed her daughter Pamina and the sun circle of power. In her fury she is requesting from Pamina to kill 
Sarastro. In our version of the magic flute the boys propose to the Queen a reasonable reconsiliation with Sarastro. After reflection and meditation, the Queen agrees, if Sarastro, (teaching later in his 'hall aria' ('In these sacred halls...') to love each other free from vengeance and to forgive his enemy.) gives freedom to Pamina and hands over the sun circle. Meanwhile the girls convince Papageno to let the birds free and to become beekeeper, as bees need help. See the film 'More than honey'. Papageno finds a woman, calling her Papagena, but is separated from her, because he cannot keep silence. This is also difficult for Pamina, falling in love with Tamino, who comes to the temple to save her from slavery.

G: The boys and the Magic Flute help Tamino to fulfil laws and orders of the temple*, where he is taken as prisoner. The sounds of his Magic Flute attract like the music of Orpheus wild animals and help Pamina and Tamino at the end to traverse fire and water. With support of the boys Pamina and Tamino as well as Papagena and Papageno are at last reunited. With sounds of the magic bells the boys bring Papagena back by plane* The temple, containing a temple of nature, wisdom and reason, is illuminated as the stage by the sun (Figure 2).

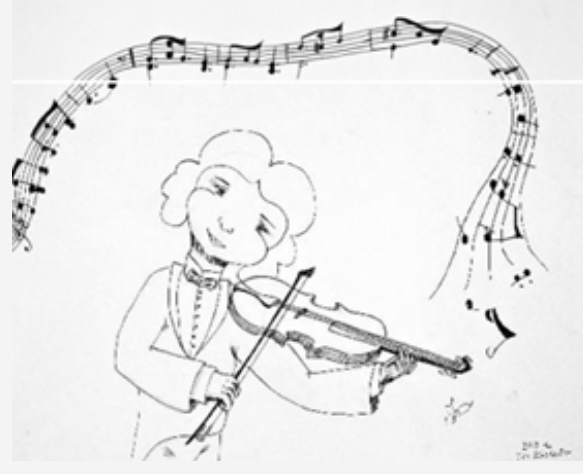

Figure 2

S: Deeply touched by the paintings and solutions from the children, their wisdom and intelligence, Sarastro is asking for a short presentation of the Creation, explaining the Genesis and history of the Earth, of Life and of man in his upliftment to humanity.

G: The sun, female in German, Center of our Solar System, discovered by Copernicus, already praised by Echnaton, Akenathen in ancient Egypt and St. Francis, gives light and energy for free to all humans, plants and animals as well to our stage, appearing now as the beautiful space ship Earth embellished by Mozart's Magic Flute in honor of our solar system, discovered by Copernicus, loved by earth children. Now the hole universe appears on a screen with words of Leibniz in Latin: Omnibus

ex nihilo ducendis sufficit unum', Spektrum der Wissenschaft', journal, presented in the first edition 2008 the universe as quantum computer consisting of zeros and ones. In honor of Copernicus, Kepler, Leibniz,

B: Mozart, Einstein, Planck, Heisenberg, Arber, Bin nig \& Co. we praise the one, giving birth to all things in the universe. Praising the Creation, we want to help to preserve it in the veneration of the one, source or deity, having created man according to the Genesis in its image, giving birth to heaven and earth, plants and animals, among them the bee, considered as equal to the royal hiero-glyphe of highest value in ancient Egypt's hierarchy. Genesis of our earth (Figure 3).

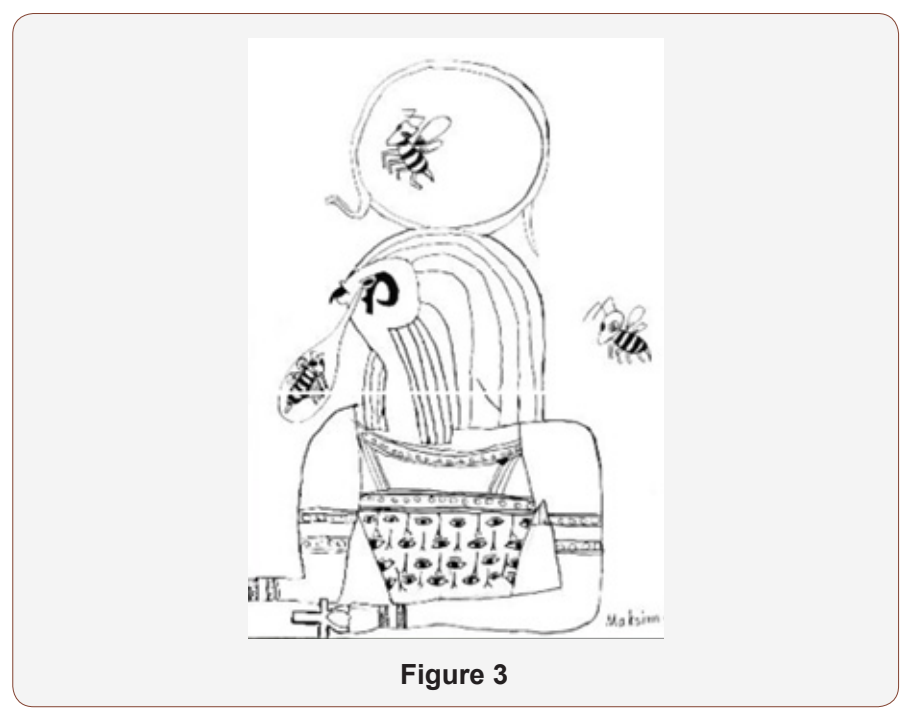

In its beginning the earth appears in the universe... compared with the sun as small but less hot fireball, building a crust the continents later on come from, when the earth, as we are told, is becoming so cold, that the crust is breaking and the continental drift is giving birth to a new shape of our earth: Five continents appear as result of this game, Africa, America, Asia, Australia and Europe by name

The Quantum Society becoming sustaining: See, Die Strategie der Genesis' of Rupert Riedl and .Stufen zum Leben' of M. Eigen. Eigen's later mentioned article on Mozart or our inability to understand the genius is part of his book, Jenseits von Ideologien und Wunschdenken.' ('Beyond ideologies and wishful thinking') See also Karl

Popper's, Alles Leben ist Problemlösen' (All Life is Problem Solving)

\section{Genesis of Life}

G: Step by step Life becomes (up) to be in the different spheres of the land and sea, performing with RNA and DNA, cells and membranes its start, developing diversity through a most efficient art:What cells, genes, proteins and enzymes succeed to create, leads to fitness and beauty, which we celebrate. Over the crystals life begins its games, giving birth to plants and animals of different names: From earliest form of life to insects, birds, fishes and the crocodile, as well to whales and dolphins, playing meanwhile, up to the mammals, coming up to the land, lion, tiger, jaguar, cheetah, overtaking them all in the end. Others move slowly like Capricorns, rams and elephants and the clever monkeys already use their hands. Genesis of man/The film on Kent Nagano, Arte, illustrates with Daniel Levitin the importance of music in the human development. Nature is creative, as you see, so that plants, animals and man came to be. Man learns to sing and to dance with delight, to speak to fellow men and to walk upright, in search for food, shelter and beings to admire, producing and using instruments, earth, air, water, wind and fire. 
Genesis of Civilisation, see Gell-Mann's view of, cultural DNA and Auguste Rodin, Die Kathedralen Frankeichs', Emil Vollmer Verlag. For Rodin the cathedrals, evoking feelings of confidence, peace and harmony, corresponding to laws of nature, are Mozart's teacher.

G: Man invents perfume and designs, music, paper, alphabets out of signs, wheels, cars, bricks, seals and letters, ships and whatever matters in traffic, taming animals and using their energy in agriculture as basis of human economy, builds villages and towns, where rivers, lakes or sea areas are near, craftsmen, farmers, fishermen, merchants, artists and researchers start their activities here.' / For overcoming racism by science the book 'Verschieden und doch gleich - Ein Genetiker entzieht dem Rassismus die Grundlage' ('Different but equal - A geneticist, removes the basis of racism') of Luca and Francesco Cavalli-Sforza is helpful. Prof. Luca Cavalli-Sforza taught at Stanford University. For that Sarastro gives Pamia freedom, transferring the sun circle, celebrated by children together with the little Prince, who came back.

Pamina: In order to create, free from any racist ideology and anxiety, with children, women and men a sustaining solar society..

Tamino: Sounds of my Magic Flute, noble present of the Queen of the Night, unite yin and yang to peace and harmony..., Monostatos, former slave overseer of Sarastro, who fell in love with Pamina, later with the Queen: .... helping to free us from slavery.

Queen: Appealing to our better nature and responsibility, the children turn(ed) hate into love's helpful energy. Thanks to the children...,

Pamina: to the Queen, Sarastro, Papageno, Tamino and to all of you, helping to make dreams come true and not too late, so let's celebrate-.

G: Playing the role of the three ladies sustainingly, we invite you to do your best to preserve the biodiversity of our spaceship earth, dancing and celebrating with us, discovering beautiful verses of Wordsworth in Roger Sperry's 'Science and Moral Priority' after regarding the children's last painting, evoking confidence, leading us with Wordsworth's verses to ourselves, confirming Humboldt's letter of 1800 to Schiller.

Impressum: Copyright 2019, Konrad Frischeisen, The Magic Flute I \& II as holistic healing approach in honor of Asclepios, Copernicus \& Co., an abbreviated sustaining adaption of the Magic Flute, continued and decoded according to split brain research of Sperry, New Frontiers in Science Bildungsgesellschaft mbH, Munich, all rights \& errors reserved, Mail: frischeisen@ehims.de ISBN: 978-344465-14-2 Pictures of Copernicus, Columbus, Vasco da Gama, Marco Polo, Meister Bertram and his Creation of animals, Erasmus, Michelangelo and his his Creation and Moses, appear on screen, likewise of Leonardo, Raffael, Mercator,

Kepler, Galilei, Fermat, Pascal, Leibniz, Newton, Shakespeare, Marlow, Milton, Novalis, Byron, Hölderlin, Wordsworth, Matthias Claudius, Händel, Bach, Beethoven, Haydn, Mozart, Kant, Herder, Humboldt/s, Goethe, Pesta-lolozzi, Schiller, Pasteur, Dos- totojewski,
Tolstoi, Chagall, Picasso, Havel and of Nobel Laureates like Marie Curie, Banting, Bergson, Bohr, de Broglie, Planck, Einstein, Dirac, Heisenberg, Pauli, Raman, Bertav. Suttner, inven- ttor of Nobel Prizes, Fleming, Be- Beckett, Camus, Hesse, Jiménez, O’Neill, Röntgen, Koch, Schrödinger, Pauling, Chandrasekhar, Delbrück, Feynman, Watson \& Crick, Barbara Mcclintock, Rita Levi-Montalcini, Luria, Christiane Nüsslein-Volhard, Francoise Barré-Sinoussi, Jacob, Eigen, Eccles, Gabor, Sperry, Kandel, Kastler, Mößbauer, Annan, Arber, Binnig, Blobel, Böll, Chu, Crutzen, Dylan, Elytis, Ernst, v. Frisch, Gell-Mann, Giacconi, Cohen- Tannoudji, Ertl, Nadine Gordimer, Grass, Grünberg, Hänsch, Haroche, Hell, Huber, Kastler, Ketterle, v. Klitzing, Selma Lagerlöf, Lorenz, Luther-King, Mandela, Mourou, Ashkin, Toni Morrison, Mugwege, Alice Munro, Herta Müller, Nadia Murad, Paz, Pire, Prigogine, Rolland, Russel, Sartre, Schweitzer, Sen, Shaw, Singer, Steinbeck, Störmer, Donna Strickland, Wislawa Szymborska, Tagore, Tinbergen, Tutu, Yang, Walesa, Wieman, White, Zewail \& Co. presenting discoverers, inventors, finders, who fostered art, science or peace since the Gothic. Finis Acknowledgements: The author's translation of Schikaneder's libretto of the Magic Flute is put in inverted commas. According to Peter v. Matt the Magic Flute is with Leonardo's Mona Lisa and Shakespeare's Hamlet the third great mystery of our culture. Children in our game are encouraged by Mozart's 'Idomeneo', by Beethoven variations of the 'Magic Flute' and by Busoni, proclaiming that Mozart gives with the mystery the solution. The pictures in this game were painted by children of Munich, except the pictures of the universe and of the DNA.. According to radio news in 2005*, classical music, especially of Mozart, was introduced into the Tube of London to reduce the criminal rate.

Experiments at four stations showed, that the criminal rate could thus be reduced by 33 percent. Considering Sperry's SplitBrain Research, these news can reinforce measures to reduce the criminal rate elsewhere through an education based on results of this split brain research, encouraging to use neglected potentials of the subdominant hemisphere of our brain in a more holistic, musical and visual healing way. The children in our presented version of the Magic Flute use neglected potentials in a musically and visually supported healing procedure. For that, it was helpful to introduce graceful girls into our game, playing the role of the three ladies in a different new creative way, respecting the healing wisdom of Asclepios, venerated in antiquity. Thus Goethe's intention to unify the Christian Soul with the beauty and wisdom of antiquity is actualized in honour of Mozart, his friend Josef Haydn and his oratorium 'The Creation' and in honour of Goethe's Faust, in which Thales proposed a new creation and Manto, in Goethe's view daughter of Asclepios, helped Faust to find Helena and to unify himself with her. Goethe was highly appreciating the Magic Flute, comparing it to his Faust, confessing, that he desired Mozart as composer for it. Wanting Goethe's view to be completed with Walt Whitman's view, Thomas Mann would probably have appreciated this view. Romain Rolland, who corresponded with Tolstoi and met Gandhi, saw in Mozart a source of peace. In Rolland's view Mozart was a devout believer, transcending with his musical intuition the small frontiers of a special religion and expressing the essence of 
every religion. *Source: Jan Assmann, Die Zauberflöte', for more information on Split-Brain Research please regard the author's articles 'The Brain as Peacemaker', Crimson and Juniper Publishers and 'Noble Brains and Nobel Laureates' Iris Publishers. See also books like 'Staying alive' of Roger Walsh,, Aus dem Nichts' of Gerd Binnig and of Viktor Frankl, founder of logotherapy, inspiring this game, likewise the experience of Richard Davidson, Jon KabatZinn on the healing power of meditation, Eckart Altenmüller and Tom Fritz on the healing power of music and books of Werner Heisenberg, Günther Hasinger \& Co. encouraging to join particles to the whole. The author thanks Mozart \& Co., the children and other helpful persons, artists, teachers, researchers, family members, Prof. Gabriela v. Habsburg, Dr. Stefanie Siebers- Gfaller, Dr. Valentina v. Tulechov, Prof. Sigrid Berka, Melanie Cornejo, Andrea Golla, Leah Sharp, Charis Nass, Jennifer Münch, Ludwig Apfelbeck, Gerald Hochenberger, David Marks, Dr. Karl-Heinz Maurer, the Nobel laureates Arber, Binnig, Ernst, Huber, Ketterle... / Ulrich Raasch, Dr. Harald Klückmann, Rainer Kohmann, Patrick Gruban, Marco Stohr, Lars Trebing, Dr. Carlos Acevedo-Rocha, Walter Gunz, Prof. Andreas de Bruin, Dr. Christian Lehmann, Dr. Wolfgang Schweiger, researchers of different disciplines from Bavaria and elsewhere. PS: In the preface of his book, Was ist Leben?' (What is Life?), Erwin Schrödinger wrote, that we have inherited from our ancestors a strive for universal knowledge. The growing branches of knowledge, making universal knowledge nearly impossible, Schrödinger encouraged 1944 in Dublin as solution for this dilemma an integrated view of all research options, even if others are at the origin of the new research. According to Wilhelm v. Humboldt's letter of 1800 to Schiller, poetry intervenes to lead man to himself. In Schiller's view man finds playing himself.

Alexander v. Humboldt, author of 'Kosmos', helped Schinkel, inspired by Mozart's music, to give Berlin beauty in art and buildings (Figure 4).

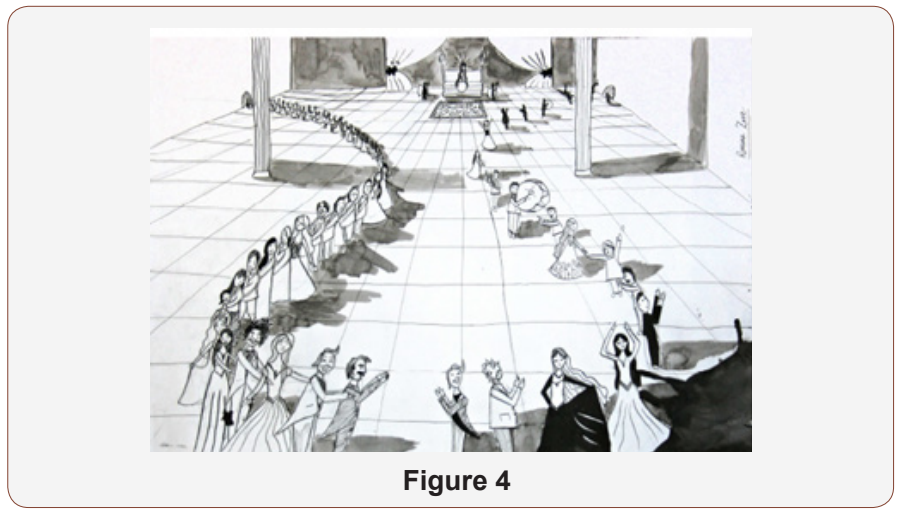

Heisenberg venerated Humboldt, appreciating Mozart's music and the little prince of Saint-Exupéry, who had learned to see with the heart. In his article, Mozart oder unser Unvermögen, das Genie zu begreifen, 'Mozart or our inability to understand the genius', Nobel laureate Eigen mentioned Sperry's split brain research and the children physicists Heisenberg, Pauli \& Co. as comparable to the genius of Mozart. If man is created in the image of a creative deity, potentials like those of Mozart, Einstein, Heisenberg, Binnig \& Co. are within children. Conclusions: Interdisciplinary cooperation with researchers, artists, teachers, children, ladies and gentlemen in all parts of our planet can foster holistic healing approaches, helping to free humanity from racism and slavery, supported by Mozart's opera, clarified and sustainingly adapted with help of children's paintings, logotherapy, meditation, good books and yoga in the service of the one creative deity of us all. Abbreviations in the text: DNA for deoxyribonucleic acid, \& Co. for and company or collegues, v. for von in front of a noble person's name.

\section{Acknowledgement}

None.

\section{Conflict of Interest}

No conflict of interest. 